\title{
STRATEGI KOMUNIKASI PEMASARAN OBJEK WISATA HIDDEN CANYON DALAM MENINGKATKAN KUNJUNGAN WISATAWAN
}

\author{
A.A. Raka Jayaningsih \\ Stikom Bali \\ gunggekraa82@yahoo.co.id
}

Ni Putu Yunita Anggreswari

Universitas Pendidikan Nasional

tata.anggreswari@undiknas.ac.id

\begin{abstract}
ABSTRAK
Bali merupakan penyumbang devisa terbesar di Indonesia. Besarnya pendapatan pulau dewata di sektor pariwisata tentu tidak terlepas dari peran komunikasi pemasaran dalam memperkenalkan destinasi-destinasi pariwisata baru yang ada di Bali. Strategi komunikasi pemasaran dilakukan dengan menggunakan bauran yang terdiri dari periklanan, pemasaran langsung, hubungan masyarakat, penjualan personal dan promosi penjualan. Penelitian ini akan berfokus pada bauran komunikasi pemasaran yang diimplementasikan dalam memperkenalkan destinasi wisata Hidden Canyon Beji Guwang. Hidden Canyon Beji Guwang merupakan objek wisata susur alam yang berlokasi di desa Guwang, Sukawati, Gianyar. Penelitian ini menggunakan metode penelitian deskriptif kualitatif karena berusaha menampilkan dan menjelaskan fenomena yang ditemukan di lapangan. Adapun teknik pengumpulan data yang digunakan dalam penelitian ini adalah teknik observasi yakni melakukan pengamatan langsung pada objek penelitian. Teknik pengumpulan data juga menggunakan teknik wawancara dan dokumentasi. Wawancara dilakukan dengan mewawancarai beberapa informan yang terdiri dari kepala desa adat Guwang, manajer dan pengelola Hidden Canyon, wisatawan mancanegara maupun wisatawan domestik, serta beberapa tokoh masyarakat. Hasil dari penelitian ini adalah bahwa Hidden Canyon menerapkan bauran komunikasi pemasaran sebagai upaya untuk meningkatkan brand awareness yang terdiri dari periklanan, penjualan personal, pemasaran langsung, hubungan masyarakat dan publisitas serta promosi penjualan. Hidden Canyon menerapkan periklanan dengan cara beriklan di televisi untuk menjangkau wisatawan domestik, iklan juga dimuat dalam media cetak lokal. Sementara itu pemasaran langsung dilakukan dengan cara menjalin kerjasama dengan tour travel di Bali. Penjualan personal sendiri diterapkan oleh seluruh pengelola Hidden Canyon yang mana seluruh pengelola serta guide Hidden Canyon dibekali dengan kemampuan untuk melakukan personal selling. Seluruh pengelola juga berperan sebagai Public Relations yang bertugas untuk menjaga hubungan antara pihak internal dan masyarakat eksternal. Sementara itu dalam promosi penjualan Hidden Canyon menawarkan paket-paket harga yang menarik untuk wisatawan.
\end{abstract}

Kata Kunci: Strategi, Komunikasi Pemasaran 


\begin{abstract}
Bali is an island that contributed a huge number of foreign exchange of tourism in Indonesia. It happened cause the growth of tourism sector and the use of marketing communication strategy that allow the tourist to develop their knowledge of new tourism destination. The marketing communication strategy is consist of : advertising, direct marketing, public relations, personal selling and sales promotion. This research focused on the integrated marketing communication mix that used to develop the brand awareness of Hidden Canyon Beji Guwang. Hidden canyon is a tourist attraction that located in Guwang village, Gianyar Regency, Bali. This research use three kind of data collection methods that consist of : interviewing, observation and documentation. The informant is consist of : Bendesa Guwang, Manager of Hidden Canyon, foreign and domestic tourists. Based on the interview, Hidden Canyon use the marketing communication mix as a strategy to develop the brand awareness from the foreign and domestic tourist. The Hidden Canyon's management team advertised on newspaper, local and national television station to send informations for domestic tourists. All of the management team educated to develop a good personal selling skill in order to persuade the tourists. As for the direct marketing, the management made a good use of social media and build a relationship with many tour travel in Bali. All of the management team had a role as public relations to mantain a good relationship with the internal and external public of Hidden Canyon. To persuade the tourists, management team create many tour packages that offers a great deal.
\end{abstract}

Keyword : Strategy, Marketing Communications

\title{
Latar Belakang Masalah
}

Bali merupakan salah satu pulau di Indonesia yang memiliki potensi pariwisata. Besarnya minat wisatawan untuk mengunjungi Bali menyebabkan Bali tidak berhenti melakukan inovasi untuk mengembangkan potensi objek wisata yang dimiliki. Persaingan dalam dunia pariwisata mengakibatkan pengelola objek wisata harus melakukan strategi komunikasi pemasaran secara terpadu untuk meningkatkan dan mempertahankan jumlah kunjungan wisatawan. Komunikasi pemasaran merupakan suatu kegiatan pertukaran pesan yang memiliki tujuan untuk membujuk komunikan atau penerima pesan. Menurut Saladin, (2001:123) "Komunikasi pemasaran adalah aktivitas yang berusaha menyebarkan informasi, mempengaruhi dan membujuk atau meningkatkan pesan sasaran atas perusahaan dan produknya agar bersedia menerima, membeli loyal pada produk yang ditawarkan perusahaan yang bersangkutan”.

Menurut Tannenbaun dan Lauterborn, komunikasi pemasaran sebagai proses berkesinambungan mulai dari tahap perencanaan produk. Mereka menegaskan bahwa pemasaran adalah komunikasi dan komunikasi adalah pemasaran. Keduanya tidak dapat dipisahkan (Hasli, 
2012: 28). Dengan adanya komunikasi pemasaran, konsumen dapat menyadari akan kehadiran dan keunggulan suatu barang atau jasa. Komunikasi pemasaran memiliki peranan sangat penting dalam memfasilitasi hubungan yang saling menguntungkan antara perusahaan dan konsumen, karena komunikasi pemasaran mendorong konsumen untuk melakukan pembelian yang menguntungkan bagi pemasaran dan kepuasan bagi konsumen.

Strategi komunikasi pemsaran dilakukan dengan menggunakan bauran yang terdiri dari periklanan, pemasaran langsung, hubungan masyarakat, penjualan personal dan promosi penjualan. Untuk mendapatkan hasil komunikasi pemasaran yang maksimal, kelima bauran tersebut harus diaplikan secara terintegrasi. Komunikasi pemasaran bukanlah sebuah strategi yang hanya dirancang dan digunakan oleh perusahaan-perusahaan besar, namun harus digunakan juga dalam pengelolaan suatu objek wisata. Hidden Canyon merupakan salah satu objek wisata di Bali yang terletak pada Desa Guwang, Kabupaten Gianyar. Secara resmi, Hidden Canyon telah berdiri sejak tahun 2012 dan berhasil menarik perhatian wisatawan lokal maupun mancanegara. Sebagai suatu objek wisata yang juga merupakan bagian dari Badan Usaha Milik Desa, Hidden Canyon dikelola oleh pihak Desa Guwang. Sejak secara resmi beroperasi, Hidden Canyon telah berhasil meningkatkan jumlah kunjungan wisatawan dan awareness para wisatawan. Hidden Canyon dengan keunikan landscape yang dimiliki telah berhasil menjadi salah satu obyek wisata yang wajib dikunjungi di Bali. Bagi suatu objek wisata, faktor yang terpenting untuk tetap mempertahankan keberadaannya adalah tingkat kunjungan wisatawan. Keberhasilan Hidden Canyon dalam meningkatkan jumlah kunjungan wisatawan tidak terlepas dari strategi komunikasi pemasaran yang telah dijalankan.

\section{Rumusan Masalah}

Berdasarkan penjabaran latar belakang di atas, adapun permasalahan yang dapat dirumuskan adalah bagaimanakah strategi komunikasi pemasaran yang dilakukan oleh Hidden Canyon dalam meningkatkan jumlah kunjungan wisatawan? 


\section{Tujuan Penelitian}

Tujuan penelitian pada artikel ini adalah untuk mengetahui strategi komunikasi pemasaran yang dilakukan oleh Hidden Canyon dalam meningkatkan jumlah kunjungan wisatawan.

\section{Kajian Teori}

\section{Komunikasi Pemasaran}

Komunikasi merupakan salah satu faktor penting dalam melakukan kegiatan pemasaran. Menurut Sutisna (2001: 267) komunikasi pemasaran didefinisikan sebagai berikut: "Komunikasi pemasaran merupakan usaha untuk menyampaikan pesan kepada publik terutama konsumen mengenai keberadaan suatu produk di pasar". Bagi seorang komunikator, jelas bahwa komunikasi pemasaran haruslah bisa menciptakan keintiman dan nuansa pertukaran dalam berkomunikasi dengan komunikan sehingga tidak menimbulkan anggapan atau citra negatif. Inti dari komunikasi pemasaran adalah bagaimana produsen dapat menjangkau konsumen secara efektif sehingga terjadi perubahan sikap terkait dengan keputusan dalam pembelian suatu produk.

Komunikasi pemasaran memiliki efek yang kuat kepada konsumen apabila dilakukan secara langsung, terus menerus dan terintegrasi. Hasil akhir dari komunikasi tersebut adalah adanya perubahan sikap lawan bicara atau komunikasi yang diartikan sebagai sikap menerima komunikan akan pesan yang dibawa oleh komunikator dalam pertukaran yang dimaksud. Perubahan atau respon yang dimaksud meliputi, adanya efek kognitif, yaitu bertujuan untuk membentuk kesadaran informasi tertentu. Perubahan kedua adalah perubahan yang didasari oleh efek afektif, yang memberikan pengaruh kepada konsumen untuk melakukan sesuatu. Hasil akhir yang diharapkan adalah terjadinya pembelian. Perubahan ketiga didasari oleh adanya efek konatif atau perilaku yaitu membentuk suatu pola pada khalayak, sehingga menjadi perilaku selanjutnya yang dilakukan secara berulang kali. Perilaku yang diharapkan adalah pembelian ulang. 


\section{Bauran Komunikasi Pemasaran}

Bauran komunikasi pemasaran merupakan penggabungan dari lima model komunikasi dalam pemasaran, yaitu; periklanan, promosi penjualan, hubungan masyarakat, penjualan pribadi dan pemasaran langsung.

1. Periklanan

Periklanan adalah semua bentuk presentasi nonpersonal dan promosi ide, barang atau jasa yang dibayar oleh sponsor tertentu. Dalam kehidupan masyarakat yang sudah maju dan kompleks, iklan berevolusi ke dalam sistem komunikasi vital masyarakat, terutama dunia bisnis. (Prisgunanto, 2006: 73). Iklan merupakan salah satu bentuk promosi yang paling dikenal dan paling banyak dibahas orang. Keuntungan lain dari beriklan melalui media massa adalah kemampuannya menarik perhatian konsumen terutama produk yang iklannya popular atau sangat dikenal oleh masyarakat (Morrisan, 2010: 19).

2. Promosi Penjualan

Promosi penjualan adalah bentuk persuasi langsung melalui penggunaan berbagai insentif yang dapat diatur untuk merangsang pembelian produk dengan segera dan atau meningkatkan jumlah barang yang dibeli pelanggan (Hermawan, 2012: 128). Pada sarana komunikasi pemasaran, sales promotion dan pameran adalah memiliki efek yang singkat sebagai upaya menstimulasi tekanan pada sikap pembelian. Asumsi ini berangkat dari kebiasaan orang yang akan membeli sesuatu barang tidak akan merencanakan sesuatu itu secara mendadak, hal inilah yang akan terjadi pada penjualan lewat sarana ini. (Prisgunanto, 2006:75).

3. Hubungan Masyarakat dan Publisitas

Hubungan masyarakat merupakan upaya komunikasi menyeluruh dari suatu perusahaan untuk memengaruhi persepsi, opini, keyakinan, dan sikap berbagai kelompok terhadap perusahaan tersebut (Hermawan, 2012: 151). Cutlip mendefinisikan humas sebagai usaha terencana untuk memengaruuhi pandangan melalui karakter yang baik serta tindakan yang bertanggung jawab, didasarkan atas komunikasi dua arah yang saling memuaskan (Morrisan, 2010: 27). 


\section{Penjualan Personal}

William G. Nickels mendefinisikan penjualan personal sebagai interaksi antar individu, saling bertemu muka yang ditujukan untuk menciptakan, memperbaiki, menguasai, dan mempertahankan hubungan pertukaran yang saling menguntungkan dengan pihak lain (Hermawan, 2012: 108).

5. Pemasaran Langsung

Pemasaran langsung adalah pendekatan pemasaran yang bersifat bebas dalam menggunakan saluran distribusi dan/atau komunikasi pemasaran, yang memungkinkan perusahaan memiliki strategi sendiri tersendiri dalam berhubungan dengan konsumen (Hermawan, 2012: 183). Didorong oleh kemajuan teknologi komunikasi, maka kini tidak sulit lagi untuk melakukan komunikasi interaktif melalui media massa, dalam hal ini yang utama adalah melalui internet. Dengan menggunakan fasilitas world wide web (www), memungkinkan terjadinya arus informasi timbal balik sehingga pengguna dapat berpartisipasi dan memodifikasi bentuk dan isi informasi pada saat itu juga. Kehadiran internet tidak saja telah mengubah cara-cara perusahaan dalam merancang dan melaksanakan strategi bisnis dan pemasaran namun juga memengaruhi program komunikasi pemasaran yang mereka gunakan. Hal ini memungkinkan perusahaan untuk menyampaikan informasi dan melakukan interaksi melalui fasilitas yang ada di website kepada konsumen mereka.

\section{Strategi Komunikasi Pemasaran}

Strategi merupakan simpulan taktik dalam keperluan bagaimana tujuan yang diinginkan dapat diperoleh atau didapat. Oleh sebab itu strategi biasanya terdiri dari atas dua atau lebih taktik, dengan anggapan yang satu lebih bagus dari yang lain. Dengan demikian ,strategi merupakan kumpulan taktik dengan maksud tujuan dan sasaran dari perusahaan, institusi atau badan (Hasli, 2012: 20). Penting bagi produsen untuk merencanakan strategi demi meraih tujuan. Menurut Basu Swastha dan Handoko (2000 : 67), "Strategi komunikasi pemasaran merupakan rencana yang diutamakan untuk mencapai tujuan". Beberapa perusahaan mungkin 
memiliki tujuan yang sama tetapi strategi yang digunakan untuk mencapai tujuan tersebut dapat berbeda, sehingga strategi komunikasi pemasaran diterapkan sesuai dengan tujuan. Strategi komunikasi pemasaran menggambarkan pesan yang akan dibagi dengan target pelanggan (audiens) khusus melalui komunikasi pemasaran yang optimum.

\section{Metode Penelitian}

Penelitian ini merupakan penelitian deskriptif kualitatif karena berusaha menampilkan dan menjelaskan fenomena yang ditemukan di lapangan. Menurut Bogdan dan Taylor, penelitian kualitatif adalah prosedur penelitian yang menghasilkan data deskriptif berupa kata-kata tertulis atau lisan dari orang-orang yang berperilaku yang dapat diamati yang diarahkan pada latar dan individu secara holistik (utuh) (Gunawan, 2013: 82). Obyek dari penelitian ini adalah obyek wisata Hidden Canyon yang terletak di Desa Guwang, Kabupaten Gianyar, Bali.

Teknik pengumpulan data yang digunakan dalam penelitian ini adalah observasi, wawancara dan dokumentasi. Observasi yakni pengamatan langsung yang dilakukan di objek penelitian, dokumentasi adalah teknik pengumpulan data dengan menggunakan dokumendokumen terkait dan wawancara adalah teknik pengumpulan data dengan melakukan tanya jawab dengan beberapa informan terkait. Informan pada penelitian ini adalah direktur pengelola Hidden Canyon Beji Guwang, kepala desa adat Guwang beserta wisatawan domestik dan mancanegara. Teknik analisis yang digunakan adalah model interaktif yang dilakukan dengan cara data collections (data dikoleksi), data reductions (data direduksi), melakukan display dan mengambil keputusan dan verifikasi.

Untuk menguji keabsahan data yang didapatkan, pada penelitian ini digunakan teknik triangulasi data dan triangulasi teori. Triangulasi data merupakan pengecekan data yang dilakukan dengan membandingkan sumber data yang berbeda untuk menggali data yang serupa. Triangulasi teori adalah pengecakan data yang dilakukan dengan menguraikan pola, hubungan dan menyertakan penjelasan yang muncul dari analisis. 


\section{Hasil Penelitian}

Berdasarkan teknik pengambilan data yang telah dilakukan, diketahui bahwa pengelola obyek wisata Hidden Canyon telah mengaplikasikan bauran komunikasi pemasaran dalam menarik minat wisatawan untuk berkunjung. Bentuk-bentuk bauran komunikasi pemasaran yang telah dilakukan adalah sebagai berikut :

1. Periklanan

Iklan merupakan salah satu bentuk bauran komunikasi pemasaran yang efektif untuk menjangkau konsumen secara luas. Sadar akan hal ini, pengelola Hidden Canyon telah beriklan baik melalui media lokal maupun media nasional. Konten iklan yang disajikan pun beragam, disesuaikan dengan media dan audiens yang menjadi sasaran. Untuk menyasar audiens lokal di Bali, pengelola Hidden Canyon beriklan pada media TV lokal seperti Bali TV dan media surat kabar yang dilakukan melalui Bali Post. Tidak hanya menyasar masyarakat lokal di Bali, pihak pengelola juga beriklan menggunakan media nasional seperti pada Kompas TV.

2. Promosi Penjualan

Promosi penjualan merupakan salah satu bauran komunikasi pemasaran yang memiliki efek dalam memberikan stimuli bagi konsumen untuk melakukan pembelian terhadap produk. Pada awal berdiri, obyek wisata Hidden Canyon memasang tarif yang berbeda antara tiket masuk dengan biaya untuk pemandu yang telah disediakan. Wisatawan diberikan kewenangan untuk memberikan donasi secara sukarela terhadap pemandu. Untuk memperbaiki sistem ini dan menambahkan stimuli bagi para wisatawan, maka sejak tahun 2018, pengelola menyediakan promosi penjualan dalam bentuk paket wisata yang telah termasuk ke dalam biaya tiket masuk, pemandu, wifi, serta handuk dan air mineral. Paket wisata tersebut terdiri dari :

a) Individual Package untuk satu orang wisatawan seharga Rp. 125.000.00.

b) Couple Package untuk dua orang wisatawan seharga Rp. 150.000.00.

c) Pty Package untuk 3 hingga 4 orang wisatawan seharga Rp. 200.000.00.

d) Small Group Package untuk 5-9 orang wisatawan seharga Rp. 425.000.00.

e) Middle Group Package untuk 10-14 orang wisatawan seharga Rp. 650.000.00.

f) Group Package untuk 15-19 orang wisatawan seharga Rp. 850.000.00 
3. Pemasaran Langsung

Pengelola Hidden Canyon menyadari bahwa suatu obyek wisata harus pro aktif dalam mempromosikan keunikan yang dimiliki. Untuk itu, pengelola melakukan kerjasama dengan berbagai agensi travel dan guide yang kemudian akan menambahkan Hidden Canyon sebagai salah satu destinasi yang wajib dikunjungi dalam agenda tur para wisatawan. Pemasaran langsung melalui agensi travel menjadi faktor yang efektif dalam mendekati wisatawan mancanegara. Kehadiran internet yang memberikan kemudahan bagi pemasar untuk menjangkau audiensnya juga dimanfaatkan dengan baik oleh Hidden Canyon. Pengelola menggunakan media sosial untuk menyebarluaskan keberadaan dan keindahan alam yang ditawarkan. Melalui akun instagram dan facebook resminya dengan nama "hidden canyon beji guwang", pengelola secara aktif menampilkan gambaran keindahan Hidden Canyon beserta kegiatan-kegiatan para wisatawan dan promosi yang ditawarkan. Kehadiran media sosial yang dikelola secara langsung membuat Hidden Canyon lebih mudah dalam menjangkau dan mendekatkan diri dengan publik eksternalnya.

4. Hubungan Masyarakat

Untuk menjaga kelangsungan suatu perusahaan, hubungan masyarakat merupakan salah satu faktor yang penting karena merupakan jembatan antara perusahaan dengan audiens eksternalnya. Sebagai obyek wisata yang sedang berkembang, Hidden Canyon belum memiliki divisi hubungan masyarakat yang terpisah dengan divisi lainnya. Setiap pegawai memiliki peran dan berfungsi sebagai jembatan antara Hidden Canyon dengan publik eksternalnya. Agar terjaganya hubungan yang baik dengan para wisatawan, pihak Hidden Canyon menawarkan excellent service untuk menjaga citra organisasi di kalangan wisatawan, sementara itu untuk menjaga hubungan yang baik dengan masyarakat desa Guwang pihak pengelola juga menyelenggarakan simakrama secara rutin agar Hidden Canyon dapat berkontribusi kepada kebutuhan masyarakat desa adat sesuai dengan kebutuhan dari masyarakat adat itu sendiri.

5. Penjualan Personal

Sentuhan dan kedekatan merupakan salah satu hal yang penting bagi pemasar dalam memberikan stimuli bagi publiknya. Memahami hal ini, para guide beserta seluruh 
pegawai dibekali pengetahuan yang memadai dalam penggunaan bahasa asing seperti bahasa Inggris dan Jepang untuk memudahkan dalam berkomunikasi dengan wisatawan. Mereka juga dibekali dengan pengetahuan mengenai obyek wisata Hidden Canyon itu sendiri sehingga dapat menjelaskan dan merangsang para wisatawan untuk membeli salah satu paket yang ditawarkan.

\section{Pembahasan}

\section{Strategi Komunikasi Pemasaran}

Komunikasi pemasaran merupakan semua elemen-elemen promosi dari marketing mix yang melibatkan komunikasi antarorganisasi dan target audience pada segala bentuknya yang ditujukan untuk performance pemasaran, (Prisgunanto, 2006: 8). Dalam komunikasi pemasaran, terdapat konsep pertukaran yang menjadi dasar dalam berjalan atau tidaknya suatu proses komunikasi. Terjadi suatu keintiman dalam tata pergaulan manusia sebagai sesuatu yang penting dalam menentukan dasar efektivitas dalam proses komunikasi. Dalam era globalisasi ini, para ahli maupun pelaku pemasaran sudah memiliki kesadaran dan pengakuan besar bahwa mereka sangat perlu komunikasi dalam memasarkan barang atau jasa.

Untuk menjalankan strategi komunikasi pemasaran secara optimal dan terintegrasi, pengelola Hidden Canyon telah melalui tiga fase strategi komunikasi pemasaran yang terdiri dari:

1. Segmentasi Pasar

Segmentasi pasar merupakan langkah awal yang harus dilakukan dalam menyusun strategi komunikasi pemasaran. Pemasar harus mengetahui dengan pasti publik sasarannya agar dapat memaksimalkan bauran komunikasi pemasaran yang digunakan. Segmen pasar dapat diidentifikasi berdasarkan lokasi geografis, pola berbelanja, daya beli, sensitivitas harga dan cara berkomunikasi dengan pelanggan (penggunaan media, sikap, minat, opini dan lain-lain). Sebagai salah satu obyek wisata yang baru dikelola, pengelola memahami bahwa segmentasi pasar Hidden Canyon terdiri dari 2 macam wisatawan yaitu wisatawan domestik dan wisatawan mancanegara. Kondisi 
Hidden Canyon yang dipenuhi oleh batu-batu besar, menciptakan pengalaman menantang bagi wisatawan dalam menelusuri ngarai sejauh 700 meter selama 1 jam tersebut. Hal ini merupakan faktor yang menjadi daya tarik bagi wisatawan mancanegara yang cenderung menyukai tantangan. Keindahan yang ditawarkan oleh Hidden Canyon yang berbeda dengan wisata alam lainnya di Bali adalah salah satu faktor yang meningkatkan minat wisatawan domestik. Hal ini sesuai dengan trend di kalangan masyarakat yang menaruh minat tinggi terhadap obyek wisata dengan keindahan alam yang unik. Untuk menjangkau wisatawan domestik yang berada di wilayah negara Indonesia, pengelola Hidden Canyon menggunakan bauran komunikasi pemasaran periklanan, yaitu beriklan pada stasiun TV lokal bali beserta stasiun TV nasional. Berbeda dengan wisatawan domestik, pengelola memaparkan informasi kepada wisatawan mancanegara melalui pemasaran langsung, yaitu mengadakan kerjasama dengan pengelola travel agent. Pengelola juga melakukan personal selling dengan membujuk dan mempengaruhi wisatawan asing yang berkunjung menggunakan pendekatan personal. Hal ini dilakukan agar lebih mudah dan efektif dalam menjangkau target market potensial.

2. Menetapkan Pasar Sasaran

Menetapkan pasar sasaran merupakan kegiatan yang dilakukan dengan mengevaluasi daya tarik masing-masing segmen dengan menggunakan variabel-variabel permintaan dari setiap segmen (misalnya biaya distribusi), biaya memproduksi produk dan jasa yang diinginkan pelanggan (misalnya biaya produksi dan diferensiasi produk), dan kesesuaian antara kompetemsi inti perusahaan dan peluang pasar sasaran. Pengelola Hidden Canyon menyadari bahwa metode pembayaran yang sebelumnya dalam bentuk donasi yang diberikan oleh wisatawan kepada guide, tidak efektif dalam meningkatkan stimulus bagi wisatawan serta tidak memberikan income yang terukur bagi pihak pengelola. Oleh karena itu, menyadari bahwa wisatawan juga membutuhkan keamanan dan kenyaman, pihak pengelola memutuskan untuk membangun toilet, ruang ganti dan loker yang nyaman bagi wisatawan. Dibangunnya loker juga memberikan rasa aman bagi wisatawan yang datang dengan membawa jumlah barang yang banyak. Rasa keamanan dan kenyamanan yang berusaha diberikan oleh pihak pengelola kemudian berbanding lurus dengan dibuatnya paket-paket biaya sebagai bentuk promosi penjualan yang dapat 
dipilih oleh wisatawan. Melalui paket-paket wisata, income Hidden Canyon menjadi lebih terukur dan sekaligus memberikan kenyamanan bagi wisatawan.

3. Menentukan Posisi Pasar

Menentukan posisi pasar merupakan aktivitas yang dilakukan untuk mengidentifikasi konsep positioning bagi produk dan jasa perusahaan yang bagi pelanggan sasaran dan tercipta citra yang diharapkan perusahaan. Positioning adalah strategi komunikasi yang berhubungan dengan bagaimana khalayak menempatkan suatu produk, merek atau perusahaan di dalam otaknya, di dalam alam khayalnya, sehingga khalayak memiliki penilaian tertentu (Morrisan, 2010:72). Positioning menjadi penting karena tingkat kompetisi yang cukup tinggi saat ini. Sebagai salah satu obyek wisata di Bali, Hidden Canyon harus mampu bersaing dengan obyek wisata populer lainnya. Sebagai bentuk diferensiasi dengan obyek wisata lainnya, maka Hidden Canyon menetapkan diri sebagai obyek wisata yang menawarkan tantangan dengan mengarungi ngarai sejauh 700 meter yang biasa ditempuh dalam waktu 1 jam, ditemani dengan guide yang berpengalaman dan mampu menambah wawasan wisatawan terkait dengan budaya Bali serta menikmati pemandangan indah yang ditawarkan. Hidden Canyon menjadi obyek wisata pertama yang menawarkan pengalaman wisata tersebut.

Pelaksanaan strategi komunikasi pemasaran tidaklah selalu berjalan lancar. Menurut Prisgunanto (2006: 21), ada beberapa kesalahan klasik yang kerap timbul dalam penerapan komunikasi pemasaran di lapangan, yaitu:

1. Hanya sedikit perusahaan yang memiliki strategi komunikasi pemasaran yang terkoordinasi dengan aktivitas komunikasi organisasi mereka sehingga banyak pelaku bisnis menggunakan komunikasi pemasaran hanya sekedar untuk perluasan fragmentasi saja, bahkan hanya dalam keperluan penciptaan gambaran kohesif dalam pikiran pelanggan, shareholders atau staf pegawai belaka.

2. Para pelaku bisnis yang sudah memiliki kesadaran akan rencana komunikasi pemasaran lebih sarat dengan rencana taktis dan anggaran pengembangan pemasaran saja, misalnya perusahaan hanya terfokus pada perencanaan sarana komunikasi periklanan saja. Padahal, banyak rencana komunikasi pemasaran taktis lain yang tidak dijalankan. Alhasil, tidak ada 
koordinasi dan integrasi yang kuat dalam rencana komunikasi secara koheren untuk bisnis perusahaan.

Tanpa ada strategi, komunikasi pemasaran tidak akan terkoordinasi dan menjadi sesuatu yang percuma. Strategi komunikasi pemasaran minimal harus memiliki enam syarat untuk efisiensi perusahaan yaitu apakah strategi dan taktik komunikasi pemasaran sesuai dengan (a) ruang, (b) waktu, dan (c) pamor perusahaan yang disesuaikan dengan (d) kepemilikan barang produksi yang mampu menyamakan dengan produksi pekerja, (e) sumber daya manusia memadai dan (f) budaya kerja yang mendukung. Singkatnya, harus ada alokasi dana tetap yang dikaitkan dengan produksi terhadap komunikasi pemasaran perusahaan. Perusahaan bisa mempromosikan produknya, tetapi harus sesuai dengan kenyataan kualitas produk dan jasa yang ada.

Hambatan yang dihadapi oleh pengelola Hidden Canyon antara lain adalah (1) pelaksanaan strategi komunikasi pemasaran yang telah terintegrasi namun belum dilakukan secara berkesinambungan, (2) belum terbentunya divisi Public Relations untuk menjadi jembatan antara Hidden Canyon dengan publik eksternalnya serta melakukan kegiatan-kegiatan publikasi. Pada strategi komunikasi pemasaran, terutama periklanan, pengelola Hidden Canyon belum beriklan secara berkesinambungan. Memasang atau menayangkan iklan dilakukan hanya pada saat-saat tertentu saja. Fungsi public relations dijalankan oleh seluruh struktur organisasi pengelola Hidden Canyon, sehingga tidak terdapat individu-individu yang fokus dan secara khusus melakukan fungsi sebagai jembatan serta melakukan kegiatan-kegiatan publikasi secara terstruktur.

\section{Strategi Komunikasi Pemasaran Untuk Meningkatkan Kunjungan Wisatawan}

Sebagai salah satu obyek wisata di Bali, pengelola Hidden Canyon telah melakukan integrasi terhadap bauran komunikasi pemasaran sebagai strategi dalam meningkatkan jumlah kunjungan wisatawan. Tingkat kunjungan wisatawan diukur berdasarkan jumlah wisatawan yang memutuskan untuk membeli paket-paket wisata yang ditawarkan oleh pengelola setiap tahunnya. Setelah mengintegrasikan bauran komunikasi pemasaran, dengan melakukan aktivitas periklanan, publikasi, penjualan personal, pemasaran langsung serta promosi penjualan yang 
menciptakan paket-paket wisata, maka jumlah wisatawan yang berkunjung dan membeli paketpaket wisata semakin meningkat serta dapat mengukur income yang didapatkan.

Hidden Canyon hingga saat ini dapat mempertahankan jumlah wisatawan domestik maupun mancanegara pada high season hingga low season. Pada musim hujan, Hidden Canyon tidak dapat beroperasi diakibatkan oleh volume air yang tinggi sehingga dapat membahayakan wisatawan yang berkunjung, hal ini menyebabkan jumlah kunjungan wisatawan akan menurun pada musim hujan.

\section{Kesimpulan}

Komunikasi pemasaran merupakan bentuk komunikasi yang kompleks dan berbeda, dimana komunikator menyampaikan pesan yang berisi kandungan persuasi, dan ketika komunikan menerima pesan tersebut diharapkan akan terjadi perubahan pikiran sehingga pada akhirnya akan terjadi pembelian. Hidden Canyon sebagai salah satu obyek wisata di Bali telah mengintegrasikan strategi komunikasi pemasaran yang bertujuan untuk meningkatkan jumlah kunjungan wisatawan.

Strategi yang diterapkan oleh Hidden Canyon berupa ; periklanan, penjualan personal, pemasaran langsung, hubungan masyarakat dan publisitas serta promosi penjualan. Untuk menjangkau target market yang merupakan wisatawan domestik, pengelola Hidden Canyon beriklan pada televisi swasta lokal dan nasional. Tidak hanya itu, Hidden Canyon juga memasang iklan pada media cetak lokal. Bentuk pemasaran langsung yang dilakukan oleh pengelola Hidden Canyon adalah dengan bekerja sama dengan tour travel yang terdapat di Bali sebagai jembatan antara pengelola dengan target market. Untuk memastikan bahwa wisatawan yang datang melakukan pembelian, maka pengelola Hidden Canyon dibekali dengan kemampuan penjualan personal, untuk melakukan komunikasi langsung secara tatap muka yang bertujuan untuk mempengaruhi wisatawan agar melakukan pembelian. Agar Hidden Canyon dapat terus mempertahankan eksistensinya, maka seluruh pengelola berperan sebagai public relations yang menjadi jembatan antara Hidden Canyon dengan publik eksternalnya dengan cara menjalin kerjasama dengan tour travel juga para guide freelance. Untuk memberikan stimuli tambahan kepada wisatawan agar melakukan pembelian dan menjaga agar income Hidden 
Canyon dapat terukur dengan baik, maka pihak pengelola membuat paket-paket wisata yang disesuaikan dengan jumlah wisatawan yang datang. Hal ini dilakukan untuk memberikan rasa kenyaman dan keamanan bagi wisatawan. Melalui strategi komunikasi pemasaran terintegrasi, Hidden Canyon mampu meningkatkan kesadaran wisatawan (brand awareness) dan mendorong terjadinya pembelian. Sehingga dengan diterapkannya strategi tersebut, Hidden Canyon dapat meningkatkan jumlah kunjungan wisatawannya di luar musim hujan, di mana Hidden Canyon sementara tidak dapat beroperasi.

\section{Saran}

Secara akademis, perlu dilakukan penelitian lebih lanjut terkait dengan evaluasi dari komunikasi pemasaran yang sudah diterapkan oleh pihak Hidden Canyon sehingga akan terdapat hasil kajian terkait dengan keberhasilan dari bauran komunikasi pemasaran yang telah dilakukan serta terbentuknya rekomendasi-rekomendasi strategi pemasaran baru yang perlu diterapkan oleh pihak Hidden Canyon.

\section{Daftar Pustaka}

Gunawan, Imam. 2013. Metode Penelitian Kualitatif: Teori dan Praktik. Jakarta: Bumi Aksara.

Hermawan, Agus. 2012. Komunikasi Pemasaran. Jakarta: Erlangga

Morissan. 2010. Periklanan: Komunikasi Pemasaran Terpadu. Jakarta: Kencana Prenada Media Group.

Prisgunanto, Ilham. 2006. Komunikasi Pemasaran: Strategi dan Taktik. Bogor: PT. Ghalia Indonesia.

Saladin, Djaslim. 2001, "Manajemen Pemasaran, Analisis, Perencanaan, Pelaksanaan dan Pengendalian”. Bandung :Lindakarya.

Sutisna, 2001. Perilaku Konsumen \& Komunikasi Pemasaran. Bandung : Remaja Rosdakarya.

Swastha, Basu dan Irawan. 2003. Manajemen Pemasaran Modern. Yogyakarta: PT. Liberty. 